\title{
Mahtuuko perhekustannusten tasaaminen sosiaalisen huollon piiriin?
}

\author{
Kirjoittanut V. J. Sukselainen.
}

Väestöpoliittiset toimenpiteet, joilla pyritään tasaamaan lapsista vanhemmille aiheutuvia kustannuksia, ovat viimeisen vuosikymmenen aikana saaneet varsin huomattavan sijan maamme sosiaalipolitiikassa. Tästä johtuu, että kysymys niiden asemasta sosiaalipolitiikan järjestelmässä sukeltautuu tuon tuostakin esiin, ilman että vakiintumista tässä suhteessa vielä olisi havaittavissa. Verraten yleistä näyttää olevan, että äitiysavustus, perhelisä ja lapsilisä sekä muut niihin verrattavat toimenpiteet halutaan lukea sosiaaliseen huoltoon. Tähän ovat epäilemättä antaneet alkusysäyksen eräät näihin tasausmuotoihin liittyneet yhteiskunnalliselle huollolle ominaiset piirteet. Sen puolesta on puhunut myöskin asioiden käytännöllisen hoidon järjestely. Sama elin - huoltolautakunta - on saanut huolehtiakseen niin sosiaalisesta huollosta kuin edellämainittujen väestöpoliittistenkin toimenpiteiden toteuttamisesta. Osoituksena siitä, että väestöpoliittisten toimenpiteiden lukemista sosiaaliseen huoltoon ei kuitenkaan ole pidetty täysin tyydyttävänä ratkaisuna, voitaneen mainita eduskunnassa lakia sosiaalihuollon hallinnosta säädettäessä käytäntöön otettu terminologia. Huoltolautakunta sai tässä yhteydessä nimekseen sosiaalilautakunta. Se jaettiin kahteen osastoon, yleiseen osastoon, jolle $\mathrm{mm}$. väestöpoliittisten lakien täytäntöönpano kuuluu, ja huoltoosastoon.

Kun Väestöliitolla viimeksimainitussa lainsäädäntötoimenpiteessä, kuten väestöpolitiikan huoltoajattelusta irroittamisessa 
yleensäkin on ollut oma osuutensa, lienee paikallaan kosketella tässä Väestöliiton 10-vuotisjulkaisussa yksityiskohtaisemmin kysymystä siitä, mahtuuko perhekustannusten tasaaminen, johon puheena olevilla tukitoimenpiteillä pyritään, sosiaaliseen huoltoon, vai onko sille varattava sosiaalipolitiikan järjestelmässä enemmän tilaa. On tietenkin myönnettävä, että terminologiset erimielisyydet ja hiustenhalkomiset ovat useimmiten hyödyttömiä. Yhteiskuntatieteissä olisi epäilemättä päästy nykyistä pitemmälle, jos menneinä vuosikymmeninä olisi jaksettu kiinnittää enemmän huomiota itse ilmiöihin ja vähemmän harrastettu uusien nimitysten antamista vanhoille käsitteille. Tiede sen paremmin kuin käytäntökään ei suuresti kostu siitä, minkälainen nimitys jollekin käsitteelle annetaan, kunhan vain ollaan selvillä, mistä kulloinkin on kysymys. Näin ollen on tavallaan tarkoituksenmukaisuuskysyınys, mitä yhteiskunnallisen huollon eli sosiaalihuollon piiriin luetaan ja mitä jätetään sen ulkopuolelle. Kun kuitenkin on kysymys uusista sosiaalipoliittisista toimenpiteistä ja tavoitteista, joita ei vielä ole tyydyttävästi nivelletty järjestelmään, tuntuisi aiheelliselta alleviivata eräitä näkökohtia, jotka näyttävät jääneen huomaamatta niiltä, jotka - nähtävästi sopivan termin puutteessa ovat tahtoneet laajentaaa sosiaalihuollon piiriä niin paljon, että uusien ilmiöiden aiheuttama termipula vältettäisiin.

Löytääksemme vastauksen otsakkeessa asetettuun kysymykseen meidän on ensiksi tarkasteltava käsitteitä sperhekustannusten tasaaminen" ja "sosiaalinen huolto». Nämä molemmat sulkee piiriinsä kolmas käsite, »tulojen tasaaminen » eli jakaantumispolitiikka, josta meidän lienee tarkoituksenmukaisinta aloittaa tarkastelumme.

Yhteiskunnallinen liike on kautta aikojen kiinnittänyt huomiota siihen, että kansalaisten toimeentulomahdollisuudet pyrkivät muodostumaan kovin epätasaisiksi. Vaikka onkin ymmärretty, että samanlaisten toimeentuloedellytysten varaaminen kaikille yhteiskunnan jäsenille monestakin syystä on mahdotonta, on kuitenkin pidetty parannusta vaativana epäkohtana sitä, että toisten yhteiskunnan jäsenten eläessä yltäkylläisyydessä toisilla on vaikeuksia välttämättömimpienkin tarpeittensa tyydyttämisessä. Libe- 
ralismin aikakaudella kyllä uskottiin yleisesti, että tämäntapaiset epäkohdat korjautuvat itsestään, talouselämän oman mekanismin turvin, mikäli ne parannusta kaipaavat. Tässä kuitenkin petyttiin. Seurauksena oli vastasyntyneen tehdastyöväenluokan aseman kurjistuminen siinä määrin, että tämä välittömästi johti reformilikkeiden syntyyn. Nykyaikainen yhteiskunta työskenteleekin siitä syystä monella muotoa tulojen tasaisemman jakaantumisen hyväksi. Niinpä meillä Suomessakin valtio niin tuloja itselleen hankkiessaan kuin näin saatuja varoja käyttäessäänkin ottaa huomioon mahdollisuutensa vaikuttaa tasaavasti tulojen jakaantumiseen. Välittömän verotuksen puolella vaikuttaa progressiivinen tulo- ja omaisuusvero tähän suuntaan varsin huomattavalla tavalla. Välillinen verotus taas pyritään kohdistamaan sellaisiin ylellisyysluontoisiin artikkeleihin, joita ihmiset varallisuutensa ja tulojensa kasvaessa suuremmassa määrässä käyttävät. Valtion kuten kuntienkin menotaloudessa esiintyy monenkaltaista sosiaalista toimintaa, joka on omiaan parantamaan vähävaraisten mahdollisuuksia välttämättömimpien toimeentulo- ja kulttuuritarpeittensa tyydyttämiseen.

Liikkeellepanevana voimana tuloja tasattaessa on käsitys, että kaikkien kansalaisten toimeentulo ei ilman yhteiskunnan väliintuloa pääse kohoamaan sille tasolle, jota vallitsevissa olosuhteissa voidaan pitää kohtuullisena ja joka tekisi heille mahdolliseksi viettää ihmisarvoista elämää. Teoreettisena päätepisteenä tällaisessa toiminnassa lienee pidettävä asiantilaa, jolloin kansalaisten tulot ovat jakaantuneet tasan, ja joka sellaisenaan tietenkin on ajatuksellinen mahdottomuus. Tätä tavoitetta tarkasteltaessa on kuitenkin helppo havaita, miten oleellinen merkitys jakoperusteella on. Thminenhän ei elä irrallisena yksilönä muuta kuin suhteellisen harvoissa tapauksissa. Tavallisesti hän on perheen jäsen. Tästä syystä joudutaan kysymään: Onko tavoitteena tulojen tasaisempi jakaantuminen henkilöiden vai tulonsaajain kesken. Vastauksesta riippuu koko jakaantumispolitiikan luonne.

Jos etsimme vastausta jakaantumispolitiikan historiasta, joudumme toteamaan, että varsin usein on tasaamistoimenpiteiden kohteena ollut vain tulonsaaja. Järjestyneen työväen työnanta- 
jiaan vastaan käymässä kamppailussa on yleensä ollut tunnuslauseena ssamasta työstä sama palkka». Sikäli kuin valtiovalta esim. minimipalkkalainsäädännön avulla tai vastaavilla toimenpiteillä on pyrkinyt kohottamaan heikoimmin palkattujen toimeentulotasoa, huomio on useimmiten kohdistunut vain tulonsaajaan. Sama havainto voidaan tehdä verotuksen alalla. Progressiivista veroa määrättäessä on tulon määrä useasti ollut ainoa näkökohta, johon huomiota on kiinnitetty. Jos kahdella henkilöllä on ollut yhtä suuri palkka, heille on monesti pantu sama vero ottamatta ollenkaan huomioon, että toinen saa nauttia palkastaan yksin, kun taas toisen on sillä elätettävä monipäinen perhe.

Jo varsin varhain on kuitenkin havaittavissa merkkejä siitä, että pelkästään tulonsaajaan kohdistuva tulojen tasaaminen ei vastaa niitä ihanteita, jotka jakaantumispolitiikalle ovat olleet keskeisiä. Sitä mukaa kuin entisaikojen suurperheet ovat hävinneet jo irrallinen ihminen on tullut yleisemmäksi ilmiöksi, on yhä selvemmin tajuttu, että jakaantumispolitiikassa tarvitaan tulojen tasaamisen rinnalla perhekustannusten tasaamista, sellaista toimintaa, jonka tarkoituksena on jakaa lapsista vanhemmille aiheutuvat kustannukset nykyistä tasaisemmin koko työkykyisen tai omistavan väestönosan harteille. Tästä ovat osoituksena sekä verolakien perheellisille entistä myötämielisemmät säännökset että monenlaiset sosiaalipoliittiset toimenpiteet, joilla siirretään lapsista aiheutuvia kustannuksia suoraan yhteiskunnan kannettaviksi tai annetaan ostovoimaa perheellisten käyttöön.

Kun tulojen tasaamisen tarkoituksena on turvata kaikille kansalaisille kohtuullinen toimeentulo, on helppo havaita, että tähän tavoitteeseen ei päästä pelkän vertikaalisen, vain tulonsaajaan kohdistuvan tasaustoiminnan avulla. Vuonna 1925 julkaisemassaan teoksessa amerikkalainen tutkija Paul H. Douglas osoitti, ettei esim. Yhdysvaltain kansantulo ollut kyllin suuri, jotta siitä clisi riittänyt jokaiselle työntekijälle niin suuri palkka kuin viisihenkinen perhe olisi vuonna 1920 tarvinnut elääkseen jossakin Amerikan suurkaupungissa. Köyhempien maiden kohdalla on tietenkin vielä vakuuttavammin osoitettavissa, että tilanne ei voisi muodostua kaikille perheille tyydyttäväksi, vaikka kansantulo 
voitaisiin jakaa tasan tulonsaajain kesken. Näin ollen tarvitaan jo tulojen tasaamisen alkuperäisen tavoitteen takia vertikaalisen tasauksen rinnalla myös horisontaalista. On kiinnitettävä huomiota siihen tosiasiaan, että yhtä suuret tulot eivät läheskään aina merkitse yhtä korkeata elintasoa, vaan että tulojen määrän rinnalla vaikuttaa elintasoon myös elatusvelvollisuuden määrä.

Ero suuren ja pienen perheen toimeentuloehtojen välillä ei kuitenkaan rajoitu vain vähävaraisiin kansankerroksiin, joiden aseman parantamiseen jakaantumispolitiikka yleensä tähtää. Se ulottuu läpi koko yhteiskunnan ja sentähden perhekustannusten tasaamisella on merkitystä myös niissä yhteiskuntaluokissa, jotka vertikaalisen tasauksen yhteydessä ovat pelkästään antavana puolena. Voidaankin sanoa, että pyrkimys yleiseen perhekustannusten tasaamiseen merkitsee omalla lohkollaan siirtymistä vanhasta, vain vähävaraisiin kansanluokkiin rajoittuneesta »työväenmenestyspolitiikasta" koko kansaan kohdistuvaan nykyaikaiseen sosiaalipolitiikkaan.

Kun perhekustannusten tasaaminen todetaan tulojen tasaamisen muodoksi, jonka vaikutusala on laajempi kuin vertikaalisen tasauksen sosiaalisesti kohottava vaikutus, astuu vuoroon yhteiskunnallisen huollon olemuksen lähempi tarkastelu. Sosiaaliministeriön julkaisemassa opaskirjasessa »Sosiaalinen lainsäädäntö ja toiminta Suomessa» käsite määritellään seuraavasti: »Yhteiskunnallisella huoltotoimella tarkoitetaan taloudellisen, terveydellisen ja henkissiveellisen tuen antamista niiden puutteessa oleville henkilöille yhteiskunnan toimesta siten, että huoltotoimenpiteiden laatu kussakin tapauksessa harkitaan henkilökohtaisesti ja sovelletaan yksilöllisen huollontarpeen mukaisesti». Meillä on yhteiskunnalliseen huoltoon totuttu lähinnä lukemaan ne toimenpiteet, jotka aiheutuvat köyhäinhoito-, lastensuojelu-, 'irtolais- ja alkoholistilaeista. Näiden rinnalla toimii vapaa yhteiskunnallinen huolto, jonka rajat eivät ole aivan selvät. Viime aikoina on yhä enemmän alettu puhua ehkäisevästä huollosta. Tämän käsitteen piiri näyttää monien tajunnassa uhkaavan venyä niin laajaksi, että harva inhimillisen toiminnan ala jää ehkäisevän huollon ulkopuolelle. 
Yhteiskunnallinen huolto on sekin eräs tulojen tasaamisen muoto. Todennäköisesti se on vanhin tapa tasata tuloja. Sille, joka elää puutteessa, annetaan armeliaisuudesta apua. Myöhemmin avunanto organisoidaan yhteiskunnan toimesta. Varoja kerätään julkisen vallan avulla ja jaetaan puutteessa oleville. Huoltoa voidaan antaa joko olemassaolevan puutteen poistamiseksi tai puutteen ennakolta ehkäisemiseksi. Oleellista on, että tarve kussakin tapauksessa tutkitaan erikseen ja apua annetaan yksilöllisen tarpeen mukaisesti. Luonnollisesti joutuu huollon kohteeksi useasti myös perhe ja silloin olemme probleemimme ytimessä, huollon ja perhekustannusten tasauksen keskinäisten suhteiden selvittelyssä.

Lapsi voi joutua huollon kohteeksi kahdesta syystä. Ensinnäkin voi yhteiskunta joutua astumaan luonnollisen huoltajan tilalle sellaisessa tapauksessa, jossa vanhemmat ovat joko kuolleet, hyljänneet lapsen tai tulleet syystä tai toisesta kyvyttömiksi huolehtimaan tämän elatuksesta. Kysymyksessä on silloin epäilemättä yhteiskunnallisen huollon perusajatus, puutteeseen joutuneen auttaminen. Toinen huollon kohteeksi joutumisen syy pohjautuu siihen, että kunta voi antaa huoltoavustusta siinä mielessä, että varaton perhe ei pääsisi joutumaan elatuksen ja huollon puutteeseen. Perheen suuruus on eräs niistä perusteista, joiden nojalla huoltoavustusta tavallisimmin annetaan. Kunta joutuu tällöin osallistumaan lapsista aiheutuvien kustannusten peittämiseen, ilman että vielä olisi puhetta perhekustannusten tasauksesta nykyaikaisessa mielessä. Tämä menettely merkitsee kuitenkin erään tärkeän periaatteellisen ratkaisun esiinmurtautumista. Yhteiskunta katsoo velvollisuudekseen avustaa työkykyistä jäsentään perheen elättämisessä sillä perusteella, että tämän elatusvelvollisuus on poikkeuksellisen suuri. Yhteiskunnalliselle huollolle ominaisen yksilöllisen harkinnan rinnalle on tällöin tunkeutumassa tietty objektiivinen arvosteluperuste, perheen suuruus. Jos toiselle annetaan avustusta sillä perusteella, että elatusvelvollisuus ylittää hänen henkilökohtaiset mahdollisuutensa, on vaikea kieltää avustusta toiseltakaan, jos tämän tulot eivät ole suuremmat ja lapsiluku on sama. 
Kun suuret perheet ovat tavallisimpia vähävaraisimman väestönosan keskuudessa, ovat huoltolakien toimeenpanijat luonnollisesti ensimmäisinä joutuneet harkitsemaan toimenpiteitä suurten perheiden toimeentulomahdollisuuksien parantamiseksi. Tästä syystä varhaisimmilla tämänsuuntaisilla toimenpiteillä on useasti ollut köyhäinhoidollinen leima. Eräissä Englannin dominioissa 1920-luvulla käytäntöön otettu minimipalkkalainsäädäntö esim. takasi lapsilisän sillä edellytyksellä, että perheen tulot yhdessä lapsilisän kanssa eivät ylittäneet tiettyä rajaa. Suomen vuonna 1943 säädetty perhelisälaki niinikään takaa määrätyn tasaussumman vain niille, joiden tulot ovat tietyn rajan alapuolella. Näillä toimenpiteillä on siis läheisesti huoltoon liittyviä piirteitä, vaikka jakelu onkin jo kaavamainen eikä ole enää yksilöllisen tarpeen harkintaan tämän kiinteämmin sidottu.

Vähitellen pyrkimys perhekustannusten tasaamiseen on kuitenkin murtanut huoltoajattelun kahleet. Lähdetään siitä, että kysymyksessä ei ole perheellisten pelastaminen suoranaisesta puutteesta, vaan sellaisen asiantilan aikaansaaminen, jolloin perheen elintaso ei enää alene samassa suhteessa kuin sen lapsiluku kasvaa. Puhdas tällaisen ajattelun tuote on meikäläinen vuonna 1948 käytäntöön tullut lapsilisä, joka annetaan jokaiselle lapsenhuoltajalle hänen varallisuuteensa katsomatta. Siinä ei ole kysymys toimeentulosta vaan samaan tuloluokkaan kuuluvien erikokoisten perheiden elinkustannuksien tietynlaisesta tasaamisesta. Jos tätä kutsutaan huolloksi, silloin annetaan sanalle huolto kokonaan toinen sisällys, mikä tähän saakka on ollut tavallista. Huollon kohteeksi joutuu tällöin koko kansa alhaalta ylös saakka.

Jos mennään tällaiseen huollon käsitteen laajentamiseen, silloin on epäilemättä jakaantumispolitiikkaa kokonaisuudessaan pidettävä yhteiskunnallisena huoltotoimintana ja huollon kohteena kaikkia niitä, jotka tuloja tasattaessa jäävät saavalle puolelle. Tähän tuskin on riittäviä perusteita olemassa. Kun huollolla alkuperäisesti on tarkoitettu puutteeseen joutuneiden auttamista yhteiskunnan toimesta, se tulisi merkitsemään jokseenkin samaa, mitä tähän saakka on ymmärretty sosiaalipolitiikalla itsellään. Käsitteenmuodostuksen kannalta on epäilemättä 
tarkoituksenmukaisinta rajoittaa huolto vain erääksi jakaantumispolitiikan osaksi, suunnilleen sellaiseksi kuin edellä esitetty sosiaalihuollon määritelmä edellyttää. Perhekustannusten tasausta voi tällöin tapahtua sekä huollon piirissä että sen ulkopuolella aina suurituloisimpiin yhteiskunnallisiin ryhmiin saakka. Ulottuuhan sosiaalipolitiikka nykyisin kansaan kokonaisuudessaan eikä enää rajoitu vain sen varjonpuolisiin osiin. 